John Carroll University Carroll Collected

9-2017

\title{
AN ISLAMIC APPROACH TO MIGRATION AND REFUGEES
}

Zeki Saritoprak

John Carroll University, zsaritoprak@jcu.edu

Follow this and additional works at: https://collected.jcu.edu/fac_bib_2017

Part of the Islamic Studies Commons

\section{Recommended Citation}

Saritoprak, Zeki, "AN ISLAMIC APPROACH TO MIGRATION AND REFUGEES" (2017). 2017 Faculty Bibliography. 99.

https://collected.jcu.edu/fac_bib_2017/99

This Article is brought to you for free and open access by the Faculty Bibliographies Community Homepage at Carroll Collected. It has been accepted for inclusion in 2017 Faculty Bibliography by an authorized administrator of Carroll Collected. For more information, please contact connell@jcu.edu. 


\section{AN ISLAMIC APPROACH TO MIGRATION AND REFUGEES}

\section{Zeki Saritoprak}

$\mathrm{s}$ is well known, one of the five pillars of Islam is to give compulsory charity (zakat). In addition to the poor and destitute, among the beneficiaries of this charity are those who are in need and are suffering. When the Qur'an says, "When they give away from what We have given them" (Surah 2:3) without indicating the reference of "what," it shows that the needs of people and the ways of helping them are numerous. Migration and being a refugee are both dire human conditions and are connected to suffering and the need for help. The word refugee is not mentioned in the Qur'an per se, but among the recipients of zakat, the Qur'an mentions a category called ibn al-sabil (see Surah 9:60). Ibn al-sabil literally means traveler. In the commentaries of the Qur'an, it has been described as "the travelers passing a city who have nothing which helps them on continuing their journey, even if they have property in their hometown" (Ibn Kathir vol. 4, 169).

\section{Migration}

This large concept of traveling can be in the form of a mass migration or an individual's personal journey. Two examples of mass migration happened at the beginning of Islam: The first was the migration of around seventy of the Prophet's followers to Abyssinia, modern-day Ethiopia, fleeing persecution in Mecca; and the second is the more famous migration of the Prophet and his community from Mecca to Medina. An example of individual migration in the Qur'an would be the migration of Moses who 
migrated from Egypt to Midian as a result of the oppression of Pharaoh. This story, which is also in the Qur'an, begins with Moses being told to flee for his safety (Surah 28:20). The Qur'an then gives the prayer that Moses said when he feared that he would be captured as he fled, "Lord protect me from the wrongdoing people" (Surah 28:21), and tells how he asked God for guidance (Surah 28:22). Now a refugee, he finds himself in the town of Midian where he meets two girls and helps them to water their sheep (Surah 28:23); this is followed by another prayer: "My Lord! Truly, I am in need of whatever good that You send down to me" (Surah 28:24). Moses is taken to see the father of one of the shepherdesses who says to Moses: "Fear not. You have escaped from the wrongdoing people" (Surah 28:25). Here in the Qur'an, we have Moses as a refugee exemplifying the actions a refugee should take: to pray for God's assistance and to be of service to those a refugee meets along his or her way. It also talks about the response of the host: to take in the refugee and give him or her shelter. Moses also exemplifies the condition of being a refugee and an immigrant (muhajir). Muhajir comes from the word hijra, which has been translated as both migration and emigration. In its verb form and as an active participle, the root $\mathrm{h}-\mathrm{j}-\mathrm{r}$, from which hijra is derived, is mentioned several times in the Qur'an.

\section{Strangers and refugees}

A similar concept in the Islamic tradition used for strangers is gharib (pl. ghuraba). The Prophet of Islam praised the strangers; he personally took care of them when they arrived in his city. Several narrators recorded versions of the same story of the Prophet speaking of the ghuraba. In one version, the Prophet said: “'Blessed are the strangers.' The companions asked, 'Who are the strangers?' And the Prophet responded: 'The strangers are the people who are stripped from their family and relatives'” (Ibn Majah, hadith no: 3388). In his book on trials, that is, turmoil (fitan), Nuaym bin Hammad records an interesting statement from Abdullah bin Umar: "Of the people, the most beloved to God are strangers." He was asked, what is a stranger? He responded: "Those who escape oppression because of their religion and get together around Jesus, the son of Mary" (Hammad vol. 1, 77). Apparently, this prominent companion of the Prophet speaks of a time of turmoil during which people will be forced to migrate and leave their towns and property. Perhaps this is near the end 
of time when Muslims believe that Jesus will descend from Heaven to Earth to bring justice. These refugees will gather around Jesus. The exact meaning of this narration is elusive, but perhaps the gathering around Jesus is symbolic of the message of Jesus: love and mercy. People who embrace the message of Jesus will be open to accepting refugees.

An essential element of the Islamic faith is the protection of the life of innocent individuals. From a theological perspective, this includes migrants and refugees who are considered innocent and hence must be protected. A further religious duty of those who are financially able to do so is to give shelter to those in need. Refugees, in turn, are bound by certain rules and regulations. Classical Islamic jurists have elaborated on some of these cases. For instance, al-Sarakhsi (d. 1090), a famous Hanafi jurist, said:

If a Muslim enters a foreign abode [dar al-harb], having been given asylum, and found a treasure if he [or she] found this in the house of some of the people he will return it to them. What is in the house belongs to the owner of the house. By accepting the asylum contract, he [or she] has guaranteed that he [or she] will not betray the trust. Therefore he [or she] is obliged to fulfill of what he [or she] promised. (al-Sarakhsi vol. 2, 215)

Similarly, al-Babarti (d. 1384) said: "When a Muslim enters a foreign abode, as a trader it is not permissible for him [or her] to harm their property or lives because he [or she] guaranteed that he [or she] will not give them any harm. Attacking after this contract is treachery and treachery is haram [forbidden]" (al-Babarti vol. 7, 17).

It is not an exaggeration to say that the religion of Islam started with migration, the great migration of the Prophet and his companions, which in fact marks the beginning of the Islamic calendar. However, this was not the first migration in Islam. The first migration occurred with a small group of the Prophet's followers to Abyssinia; this tells us much about Islam and the proper treatment of refugees. Ummu Salama, who later married the Prophet, narrates the experience of those who left Mecca for Abyssinia. After describing how the Prophet had asked them to flee Mecca for Abyssinia and how they found kindness there, she talks about how the Quraysh, the dominant tribe of Mecca, sent a delegation of two 
people and a variety of gifts. She details their experience at the court of the Abyssinian Negus or King in this way:

After visiting the patriarchs and eventually the King they said "O King, some young people left our city. They have innovated a new religion. It is different from your religion and the religion of our grandfathers and we know nothing about it. They have divided our people and they came to you so that you would protect them. Return them to us so that we can return them to their relatives and their tribes." The religious advisers of the King said, "They speak the truth, O King. Return them because these two know their people better." The King, became angry. He said "I will never do this to a certain group of people who take refuge in my land." The King brought all members of the group together and invited his advisers and bishops and the Meccan delegation, as well. Then he asked the refugee Muslims questions. He said: "These people claim that you have left their religion and you do not follow my religion nor the religion of Judaism. So tell me about the religion by which you left your people." Ja'far bin Abi Talib, the cousin of the Prophet, spoke on behalf of the group and said: "We were of their religion and their tradition. God has sent to us a Messenger. We know his lineage, his truthfulness, and his chastity. He commanded us what is good and prohibited us from what is bad. He commanded us to pray and fast and give charity and visit our relatives and all what you know of the beautiful ethics. And he recited for us a Revelation, nothing is similar to It other than It. We confirmed Its truthfulness and believed in It. And we understood that what he brought was true from God. And based on that, we left the religion of our people and they tortured us and harmed us. And when it reached to the level that we could not bear, and we could not defend ourselves, our Prophet commanded us to leave the city and come to your land, preferring you over other than you so that you will protect us from oppression." (Rahawayh 1991 vol. 4, 71)

Ummu Salama noted that the Negus asked if there was anything of the Revelation that Ja'far could recite for him, and when Ja'far recited chapter 19, the Negus and the bishops all began to cry. "Then the Negus said: 'Surely, this Word and the Word that Moses came with are all 
coming from the same niche. By God, I will not return them to you and I will not allow you to touch them'” (Rahawayh 1991, vol. 4, 71). According to Ummu Salama, the envoys left humiliated and rejected. Through his actions, the Negus exemplified the Islamic approach to refugees, one that stresses compassion, mercy, and protection over self-interest. The Prophet himself emphasizes the importance of opening the doors to those who are in need: "There is no leader who closes his door to the needy, the poor, and the destitute except that God will close the door of heaven to his poverty, neediness, and destituteness" (al-Tirmidhi, hadith no: 1332). In other words, the hadith suggest that God will close the doors of His Divine Mercy that brings prosperity and plenty to those who do not open their doors. Or, to put it another way, accepting refugees will not decrease the sustenance of the society that accepts them, quite the opposite in fact.

\section{The importance of hijra}

Despite the refuge that a small group of the Prophet's community found in Abyssinia, Muslims continued to be persecuted in Mecca. It was this persecution that would eventually lead to the second Islamic migration, that from Mecca to Medina. Given the oppression faced by the Muslim community in Mecca, it was a requirement that all Muslims in Mecca migrate to Medina; it was a religious duty. However, not all Muslims were able to do so. The Qur'an directly speaks of helpless men, women, and children unable to migrate or without means to escape: They are forgiven by God for not fulfilling the duty of migration (Surah 4:97-100). Nonetheless, these verses encourage believers to migrate and reassure those who choose to migrate when oppressed that they will find success. The Prophet of Islam and earlier prophets, like Moses, are examples to be followed.

The importance of this event in the history of Islam cannot be overstated; indeed, the importance of migration in Islam can be attested to by the fact that the calendar of Islam starts with this migration and not with the birth of the Prophet. The Gregorian calendar year 622 is $1 \mathrm{H}$ [hijra] in the Islamic tradition, the beginning of the Islamic calendar. Therefore, the history of Islam is known as before hijra (BH) and after hijra (AH). At this period of time, migration was a religious compulsory duty for every Muslim who was capable of migration. Therefore, children, women (unable to migrate), and sick people were religiously excused from 
undertaking such a journey. Those who migrated from Mecca were known as Immigrants, or al-Muhajirun; those who were already in Medina were known as Helpers, or al-Ansar. ${ }^{1}$ In the following Qur'anic verse, God praises both Immigrants and Helpers, which has great implications for our modern-day refugee situation. The Helpers who are extending their hands to the refugees and immigrants are praised in the Qur'an. Although the verse in question is about a specific case, it encompasses all situations in which some people are facing migration and others are helping them.

And the first to lead the way of the Muhajirun and the Ansar, and those who followed them in good deeds, God will be well-pleased with them and they are well-pleased with Him. And He has prepared for them gardens underneath which rivers flow, in which to dwell forever and ever. That is the mighty triumph. (Surah 9:100)

The Prophet praises the Helpers by saying, "if all people follow one path, I will follow the path of the Helpers" (al-Bukhari, hadith no: 4332). Again, in another verse, the Qur'an praises those who migrate and those who are residents and owners of houses. This verse clearly states that the immigrants are poor because they leave everything behind in their home country; thus, they are in need of help, and those who are helping them will be in a better financial situation. The Qur'an indicates that it is praiseworthy to use one's wealth to help immigrants and refugees.

It is for the poor emigrants, who were expelled from their houses and their possessions, seeking bounty from God and the pleasure of God, and are helping God and His Messenger; those are the truthful ones. And those who dwelled in the abode [Medina], and embraced belief before them love whosoever has emigrated to them, not finding in their breasts any need for what they have been given, and preferring others above themselves, even if they are in need. And those who protected themselves from the greed of their soul, those people are successful ones. (Surah 59:8-9; see also 2:218 and 3:195)

One of the greatest virtues of migration in Islam is the fact that the Prophet himself is called an immigrant. Hence, immigration itself becomes an act of worship and a praiseworthy action, especially in the face of oppression and difficult situations that might result in violence, 
conflict, and the loss of lives. Since migration is a Prophetic path, from a theological perspective, migration has a reward in the afterlife. However, in order for migration to be reward-worthy, the migration must be undertaken with sincerity and honesty. Indeed, sincerity and honesty are requirements of all acts of worship. Even today, the concept of honesty and sincerity is necessary. If a person is not persecuted and not in need, but pretends to be persecuted and in need, that person - from an Islamic theological perspective-will not receive the reward of migration; such dishonesty would be considered lying and sinful. In fact, there is a Qur'anic verse that suggests that when people are faced with such a difficult situation, God will say: "Wasn't the land of God large enough that you could have migrated?" (Surah 4:97) This verse indirectly suggests that those who have authority and power should take care of refugees because the land they apparently own is not their land but God's land. The Qur'an speaks of God as the Owner of the land; God gave people authority over the land so that they would act justly toward the oppressed and the needy. Therefore, the worldly owners and authorities should open their arms to the destitute and oppressed and open the doors of their homes to them.

While the hijra marks a milestone in Islamic history, the practice of the Prophet after the migration is also exemplary and unique, not only in the history of Islam but also perhaps in the history of humankind. One can imagine how the followers of this new religion of Islam must have felt migrating to a city that was considered strange for them; they were homesick for their own city. The Prophet was no doubt aware of this. When the Prophet heard from 'Aisha of the homesickness of Abu Bakr and Bilal, he felt pity for them and prayed to God: "O God, make the city of Medina so beloved to us; like our love for Mecca and even more" (alBukhari, hadith no: 1889). It is believed that the Prophet's prayer was accepted and that the immigrants began to love Medina. We do not have any evidence that they left the city; in fact, they remained there even after the conquest of Mecca.

\section{Muakhat: Helpers and Immigrants}

In this time period, the Prophet ordered the declaration of a bond of brotherhood, also known as muakhat, between the Helpers and the Immigrants. To help integrate the Immigrants into the community, he 
declared that each Immigrant would become a brother or a sister to one of the Helpers. It is recorded that about 100 families were bonded together in this way. Later Muslim historians would argue that the Prophet's declaration of muakhat was cautiously implemented because the Prophet knew the character of each side and each individual. Considering the modern-day needs of refugees, the Prophet's declaration of brotherhood suggests a solution to two major problems: housing and food. Helpers shared their houses and food with their immigrant brothers and sisters.

The Prophet always encouraged generosity and the sharing of food. Shortly after he migrated to Medina, a prominent Medinan rabbi, Abdullah bin Salam (d. 663), met with him. After seeing the Prophet's face, he declared that this face cannot be that of a liar and he embraced Islam. In this well-known hadith, Abdullah bin Salam describes the Prophet upon his arrival in Medina. According to Abdullah bin Salam, this is the first thing he heard the Prophet say: "O people, spread peace, give food, and pray when people are sleeping, you will enter Paradise in peace” (al-Tirmidhi, hadith no: 2485). The famous Qur'an commentator, al-Tabari (d. 923), narrates another story of the Prophet: A hungry man among the Immigrants came to the Prophet to be his guest. The Prophet was poor and had no food to provide. Therefore, he asked if anyone could host him. One of the Helpers and companions of the Prophet, known as Abu Talha (d. 654), though himself poor, took the man to his house and asked his wife to honor the guest of the Prophet and provide food. The food was enough for only one person, so Abu Talha dimmed the lights and put his children to bed. When the food was brought to the table, Abu Talha and his wife pretended to eat so that the guest of the Prophet would have enough to eat. The Qur'an praises this sacrifice and the generosity of this family (Surah 59:9). ${ }^{2}$

The generosity of the Helpers and the honesty of the Immigrants are well illustrated in the famous story of Abd al-Rahman bin Awf (d. c.654). When his brother from the Helpers wanted to share his wealth with him, he said: "May God bless your family and your wealth. Just show me the way of the market." He was so successful that he became one of the wealthiest people in Medina after a few short years. Another story that describes the generosity of the Helpers is narrated by Abu Hurayrah (d. 681): The Helpers came to the Prophet and asked him to "divide between 
us and our brother Immigrants our date farms." However, the Prophet said, "No," perhaps concerned that such a large sacrifice would cause jealousy among the children of the Helpers. They then made a new offer to the Prophet. The Immigrants, they suggested, could work in the farms with them and share the fruits. In this way, the original owners of the farms remained the owners while the Immigrants shared in the bounties that the farms produced. The Prophet accepted this offer and conveyed it to the Immigrants. Then both groups said, "we heard and we obeyed" (alBukhari, hadith no: 2325).

When people enter a new environment and come together with people from differing backgrounds, there will always be problems. The early Islamic society in Medina was no exception. The Prophet would solve any emerging problems by addressing the groups and acting justly. To support one group over the other was a remnant of the pre-Islamic era known as the era of ignorance. On one occasion, for example, two young men, one Helper and one Immigrant, were fighting. Each cried for the help of their relatives, and the fight had the potential to become a significant problem for the members of the Islamic community. As soon as the Prophet heard about the fighting, he gathered people to remind them that the behavior of supporting only one's relative without respect for justice belongs to the era of ignorance. He strongly reprimanded them and reminded them of their brotherhood.

\section{Outlook}

Theologically speaking, Islam can be described as "the greatest humanity." While medieval Islamic scholars of jurisprudence developed a body of legal theory about migration and its relationship to Islam, their legal pronouncements are no longer able to adequately address the refugee crisis of our time. Today, scholars of jurisprudence must reassess the pronouncements of the past, guided by the essential principles of Islamic law and the Qur'an to derive at new approaches to meet the challenges of our changed world. This article is not the place for such legal theorizing, but perhaps the theological underpinnings described here can be the basis for such a legal study. What I hope has become clear is that the basic principles of Islamic legal theory can be found in the protection of those in need, and love and mercy toward those on Earth. "Those who are merciful, the Most-Merciful will show mercy to them. Be merciful to 
those on earth and the One in Heaven will be merciful to you" (Abu Dawud, hadith no: 4931).

\section{Notes}

1. In accordance with convention, Helpers and Immigrants are capitalized below when the text refers to al-Muhajirun and al-Ansar.

2. See the commentary of Muhammad bin Jarir al-Tabari on chapter 59 verse 9 in his Jami' al-Bayan (Beirut: Muassasat al-Risala, 2000).

\section{Works Cited}

Abu Dawud, Sulaiman bin al-Ash'ath al-Azdi al-Sijistani, ND, al-Sunan, ed. Muhammad Abd al-Hamid, Beirut: Al-Maktaba al-Asriyya.

al-Babarti, Muhammad bin Muhammad Shams al-Din, ND, Al-Inaya Sharh al-Hidaya, Beirut: Dar al-Fikr.

al-Bukhari, Abu 'Abdillah Muhammad bin Isma'il, 1990, al-Sahih, ed. Mustafa Dayb al-Bugha, Damascus: Dar Ibn Kathir.

Hammad, Nuyam bin, 1412AH, Kitab al-Fitan, Cairo: Maktaba al-Tawhid.

Ibn Kathir, Isma'il bin Umar, 1999, al-Tafsir, ed. Sami bin Muhammad Salama, Riyadh: Dar Tayba.

Ibn Majah, Abu 'Abdillah Muhammad bin Yazid al-Qazwini, 1975, al-Sunan, ed. Muhammad Fu'ad 'Abd al-Baqi, Beirut: Dar Ihya al-Turath al-Arabi.

Rahawayh, Abu Yaqub Ishaq bin, 1991, al-Musnad, ed. Abd al-Ghafur al-Balushi, Medina: Maktaba al-Medina.

al-Sarakhsi, Muhammad bin Ahmad bin Abi Sahl, 1993, al-Mabsut, Beirut: Dar al-Ma'rifa.

al-Tirmidhi, Abu 'Isa Muhammad bin 'Isa bin Sawra, 1975, al-Sunan, ed. Ahmad Muhammad Shakir, Muhammad Fuad Abd al-Baqi, and Ibrahim Atwa, Cairo: Maktaba Mustafa al-Babi al-Halabi. 